\title{
UJI EFEK ANTIINFLAMASI EKSTRAK ETANOL DAUN SALAM INDIA (Murraya koenigii L) TERHADAP TIKUS (Rattus norvegicus) JANTAN YANG DIINDUKSI KARAGENAN 1\%
}

\author{
TEST OF ANTINFLAMMATORY EFFECT OF ETHANOL EXTRACT LEAVES SALAM INDIA \\ (Murraya koenigii L) AGAINST RAT (Rattus norvegicus) MALES INDUCED BY CARAGENAN 1\%)
}

\author{
ERNA CAHYANINGSIH ${ }^{1}$, PUTU ERA SANDHI K.Y ${ }^{1}$, INDAH MUTHIA SUSANTHI ${ }^{1}$ \\ ${ }^{1}$ Akademi Farmasi Saraswati Denpasar, Jalan Kamboja No.11A, Denpasar, Bali
}

\begin{abstract}
Abstrak: Daun salam india (Murraya koenigii L) dari famili Rutaceae merupakan tanaman terpopular di masyarakat Aceh dan termasuk daun aromatik yang sering digunakan dalam masakan dan memiliki peran serbaguna dalam pengobatan tradisional. Sejumlah khasiat farmakologi daun salam india yaitu sebagai antioksidatif, antimikroba, antibakteri, obat penurun panas, antijamur, dan untuk anti-inflamasi. Penelitian ini bertujuan untuk mengetahui aktivitas antiinflamasi ekstrak etanol daun salam india (Murraya koenigii L) pada tikus jantan yang di induksi karagenan. Rancangan penelitian ini menggunakan metode eksperimental dengan rancangan Pretest Posttest Only Randomized Control Design. Hewan uji yang digunakan adalah tikus putih jantan (Rattus norvegicus) sebanyak 30 ekor. Hewan uji dibagi 5 kelompok, yaitu kelompok kontrol negatif () diberikan suspensi CMC Na 0.5\%, kelompok kontrol positif (+) diberikan suspensi Natrium Diklofenak 50 mg, kelompok PI diberikan suspensi ekstrak etanol daun salam india dosis $50 \mathrm{mg} / \mathrm{kgBB}$, kelompok P2 diberikan suspensi ekstrak etanol daun salam india dosis $150 \mathrm{mg} / \mathrm{kgBB}$, kelompok P3 diberikan suspensi ekstrak etanol daun salam india dosis $250 \mathrm{mg} / \mathrm{kgBB}$, kelima kelompok perlakuan kemudian di induksi dengan karagenan $1 \%$. Selanjutnya diukur ketebalan telapak kaki tikus perlakuan dengan menggunakan alat jangka sorong. Untuk menguji rata-rata ketebalan telapak kaki tikus dianalisis secara statistik menggunakan uji normalitas data yaitu uji Kolmogorov-Smirnov, uji homogenitas menggunakan Levene's Test, yang dilanjutkan dengan uji One Way Anova. Hasil penelitian menunjukkan bahwa ekstrak etanol daun salam india (Murraya koenigii L) dosis $50 \mathrm{mg} / \mathrm{kgBB}, 150 \mathrm{mg} / \mathrm{kgBB}$ dan $250 \mathrm{mg} / \mathrm{kgBB}$ dan kontrol positif memiliki efek sebagai antiinflamasi dilihat dari adanya perbedaan bermakna dengan kontrol negatif. Hasil yang paling efektif sebagai antiinflamasi adalah ekstrak daun salam india dengan dosis $150 \mathrm{mg} / \mathrm{kgBB}$ dibandingkan dengan dosis $50 \mathrm{mg} / \mathrm{kgBB}$ dan $250 \mathrm{mg} / \mathrm{kgBB}$.
\end{abstract}

Kata kunci: daun salam india (Murraya koenigii L.), flavonoid, ketebalan kaki tikus, tikus putih

Abstract: Salam india leaves (Murraya koenigii L) of the Rutaceae family are the most popular crops in the Aceh community and include the aromatic leaves that are often used in cooking and have a versatile role in traditional medicine. A number of pharmacologic properties of bay leaves are as anti-oxidative, antimicrobial, antibacterial, febrifuge, anti-fungal, and for anti-inflammatory. This study aims to determine the antiinflammatory activity of ethanol extract of salam india leaves (Murraya koenigii L) in male rats induced carrageenan. The design of this study used an experimental method with Pretest Posttest Only Randomized Control Design. The test animal used is male white rat (Rattus norvegicus) as many as 30 tail. The test animals were divided into 5 groups. The negative control group (-) was given a $0.5 \% \mathrm{Na} C \mathrm{CM}$ suspension. The positive control group (+) was given a 50mg Sodium Diclofenac suspension. The PI group was given a $50 \mathrm{mg} / \mathrm{kg} \mathrm{BB}$ dosage of ethanol extract of salam india leaves. P2 group was administered Suspension of ethanol extract of salam india leaves dose of $150 \mathrm{mg} / \mathrm{kg} \mathrm{BB}$. Group P3 given the ethanol extract of salam india leaves dose 250 $\mathrm{mg} / \mathrm{kg} \mathrm{BB}$. The five treatment groups then induction with $1 \%$ carrageenan. Further measured the thickness of the foot of rat treatment using a sliding tool. To test the average of rat foot sole, statistically analyzed using data normality test that is Kolmogorov-Smirnov test, homogeneity test using Levene's Test, followed by One Way Anova test. The results showed that ethanol extract of salam india leaves (Murraya koenigii L) dose 50 $\mathrm{mg} / \mathrm{kg} \mathrm{BB}, 150 \mathrm{mg} / \mathrm{kg} \mathrm{BB}$ and $250 \mathrm{mg} / \mathrm{kg} \mathrm{BB}$ and positive control had anti-inflammatory effect seen from the significant difference with negative control. The most effective result as anti-inflammatory is salam India leaf extract at dose $150 \mathrm{mg} / \mathrm{kg} \mathrm{BB}$ compared with dose $50 \mathrm{mg} / \mathrm{kg} \mathrm{BB}$ and $250 \mathrm{mg} / \mathrm{kg} \mathrm{BB}$.

Keywords: Flavonoid, Indian Salam Leaves (Murraya koenigii L), Rat Feet Thickness, White Rat

• email korespondensi: ernafar08@gmail.com 


\section{PENDAHULUAN}

Indonesia merupakan negara yang memiliki iklim tropis dengan keanekaragaman hayati terbesar kedua di dunia setelah Brazil, Indonesia memiliki sekitar 25.000-30.000 spesies tanaman yang merupakan $80 \%$ dari jenis tanaman di dunia dan $90 \%$ dari jenis tanaman di Asia yang banyak digunakan dalam pengobatan tradisional. Dalam dekade belakangan ini di tengah banyaknya jenis obat modern di pasaran dan munculnya berbagai jenis obat modern yang baru, terdapat kecenderungan global untuk kembali ke alam (back to nature), oleh karena itu obat bahan alam menjadi semakin populer dan penggunaannya meningkat (Dewoto, 2007).

Salah satu tanaman yang berkhasiat adalah Daun salam india (Murraya koenigii L) dari famili Rutaceae. Daun salam india merupakan tanaman terpopular di masyarakat Aceh dan termasuk daun aromatik yang sering digunakan dalam masakan dan memiliki peran serbaguna dalam pengobatan tradisional (Rastina, 2015). Sejumlah khasiat farmakologi daun salam india yaitu sebagai antioksidatif, antimikroba, antibakteri, obat penurun panas, antijamur, dan untuk anti-inflamasi (Dheeraj 2014).

Menurut Risna dkk. (2015) di Kalimantan Timur, tumbuhan salam (Syzygium polyanthum) berguna sebagai antiinflamasi, dimana tumbuhan salam (Syzygium polyanthum) dari famili Myrtaceae mengandung salah satu senyawa flavonoid. Senyawa flavonoid diduga berperan memiliki efek antiinflamasi yang mekanisme kerjanya diduga menghambat jalur siklooksigenase pada jalur metabolisme asam arakidonat. Senyawa flavonoid juga terdapat pada daun tanaman salam india selain flavonoid daun salam india juga terdapat senyawa lainnya seperti saponin, alkaloid, senyawa flavonoid, terpenoid, steroid, dan antioksidan seperti tokoferol, $\beta$-karoten, lutein (Khanum et al. (2000) dan Murugesh et al. (2005) dalam Rastina 2015).

Inflamasi adalah respon perlindungan normal terhadap cedera jaringan yang disebabkan oleh trauma fisik, bahan kimia berbahaya, atau agen mikrobiologi. Inflamasi adalah usaha tubuh untuk menghancurkan organisme penginvasi, menghilangkan iritan, dan persiapan tahapan untuk perbaikan jaringan (Richard, 2014). Antiinflamasi adalah melawan atau menekan peradangan, juga agen yang bekerja seperti demikian (Dorlan, 2002).

Berdasarkan paparan tersebut maka pada penelitian ini dilakukan pengujian untuk mengetahui aktivitas anttiinflamasi ekstrak etanol daun salam india (Murraya koenigii L) terhadap udem pada telapak kaki tikus jantan yang diinduksi karagenan.

\section{BAHAN DAN METODE}

Bahan. Bahan tanaman yang digunakan dalam penelitian ini adalah simplisia daun salam india (Murraya koenigii L) yang didapat dari Jalan Bambu Kuning Utama, Br. Umebuluh Canggu, Badung Bali dan dan telah dideterminasi di Lembaga Ilmu Pengetahuan Indonesia UPT Balai Konservasi Tumbuhan Kebun Raya "EKA KARYA" Bali. Bahan lain yang digunakan sebagai penunjang penelitian ini adalah natrium diklofenak sebagai kontrol positif dan $\mathrm{CMC} \mathrm{Na}$ $0,5 \%$ sebagai kontrol negatif.

Alat. Alat-alat yang digunakan dalam penelitian ini meliputi : timbangan elektrik, wadah dari bamboo, kain hitam, oven, blender, batang pengaduk, gelas ukur, beaker glass, corong buchner ( Portable diuphragin aspirator ), mortir, stamper, kertas saring, aluminium foil, spuit $1 \mathrm{cc}$, oral sonde, toples kaca, tali, cawan porselen, sendok tanduk, vial, jangka sorong.

Hewan Percobaan. Pada pengujian ini digunakan hewan percobaan tikus jantan (Rattus norvegicus) sehat berumur \pm 3 bulan pada saat perlakuan uji dengan bobot tikus 140-290 g yang memiliki kondisi fisik sehat dan aktif.

Pengumpulan Sampel. Daun salam india diambil pada pagi hari, daun salam india kemudian dibersihkan untuk memisahkan kotoran pada sampel. Selanjutnya daun salam india dijemur dengan cara diangin-anginkan, tidak terkena sinar matahari secara langsung dan ditutupi dengan kain berwarna hitam. Daun yang sudah kering, dilanjutkan dengan proses sortasi kering untuk memisahkan benda-benda asing seperti kotorankotoran yang menempel pada saat pengeringan. Kemudian ditimbang berat simplisia kering daun salam india yang dihasilkan.

Metode. Daun salam diekstraksi dengan metode maserasi menggunakan pelarut etanol $80 \%$ selama 1 hari, setiap satu hari dilakukan pengadukan. Maserasi dilakukan tiga kali penggulangan, hasil rendaman kemudian disaring dengan menggunakan corong Buchner. Kemudian dipekatkan menggunakan oven dengan suhu $40^{\circ} \mathrm{C}$ hingga diperoleh ekstrak kental. 
Persiapan hewan uji. Semua hewan uji dipelihara dalam kondisi yang sama. Sebelum digunakan tikus diadaptasikan dengan lingkungan penelitian selama dua minggu dan sebelum pemberian perlakuan, tikus dipuasakan \pm 18 jam dengan tetap diberi minum.

Pembuatan Suspensi CMC Na 0,5\%. Sebanyak 45mg CMC Na dilarutkan dalam mortir yang berisi $9 \mathrm{~mL}$ aquadest yang telah dipanaskan, lalu dicampur dan digerus sampai homogen. Suspensi CMC Na 0,5\% digunakan sebagai kontrol negatif.

Pembuatan Suspensi Natrium Diklofenak. Pada penelitian ini digunakan dosis $50 \mathrm{mg}$ dengan faktor konversi dari manusia ke tikus dengan berat $200 \mathrm{~g}$ ialah 0,018 , maka dosis natrium diklofenak untuk tikus adalah $0,9 \mathrm{mg} / 200 \mathrm{gBB}$ yang dilarutkan dengan suspensi CMC Na 0,5\%. Suspensi natrium diklofenak digunakan sebagai kontrol positif.

Pembuatan Suspsensi Ekstrak Etanol Daun Salam India. Ekstrak Etanol Daun Salam India dibuat menjadi 3 dosis yaitu $50 \mathrm{mg} / \mathrm{kg}$ BB, $150 \mathrm{mg} / \mathrm{kg} \mathrm{BB}, 250 \mathrm{mg} / \mathrm{kg} \mathrm{BB}$ yang dilarutkan dalam suspensi $\mathrm{CMC} \mathrm{Na} 0,5 \%$. Masing-masing tikus akan diberikan $1,5 \mathrm{ml}$ suspensi ekstrak etanol.

Pembuatan Karagenan. Pembuatan Larutan Karagenin $1 \%$, sebanyak 0,1 gram karagenin ditimbang, dilarutkan dalam larutan fisiologis $\mathrm{NaCl}$ sampai $10 \mathrm{ml}$ (larutan fisiologis $\mathrm{NaCl} 0,9 \%$ ).

Pembuatan Udem. Udem dibuat dengan cara menginjeksikan sebanyak $0,1 \mathrm{ml}$ larutan karagenin $1 \%$ secara intraplantar pada telapak kaki tikus. Telapak kaki tikus ditandai sebatas mata kaki dan diukur ketebalan udem dengan alat jangka sorong.

Pengukuran Udem. Pengukuran udem dilakukan sebanyak 5 kali yaitu pre tes (sebelum perlakuan), dan setelah pemberian karagenan selama 5 jam yaitu jam ke 2, 3, 4 dan 5 jam. Kemudian diukur ketebalan edema telapak kaki masing-masing tikus dengan menggunakan jangka sorong.

Analisis Data. Data yang diperoleh dianalisis dengan uji Kalmogorof Sminorf untuk melihat distribusi data dan dianalisis dengan uji Levene untuk melihat homogenitas data. Jika data terdistribusi normal dan homogen maka dilanjutkan dengan uji Analisis Varians (ANOVA) dengan taraf kepercayaan 95\% sehingga dapat diketahui apakah perbedaan yang diperoleh bermakna atau tidak. Jika hasil yang di dapat bermakna dilanjutkan dengan uji Beda Nyata
Terkecil (BNT) dengan metode LSD untuk melihat perbedaan antar kelompok perlakuan bermakna atau tidak bermakna.

\section{HASIL DAN PEMBAHASAN}

Metode ekstraksi yang digunakan pada penelitian ini adalah maserasi, maserasi adalah proses pengekstrakan simplisia dengan menggunakan pelarut dengan beberapa kali pengocokan atau pengadukan pada temperatur kamar (Dirjen POM, 2000 dalam Margareta 2016). Pelarut yang digunakan dalam penelitian ini adalah etanol 80\%, penggunaan pelarut campuran alkohol dan air merupakan pelarut ideal karena pelarut pengekstraksi yang terbaik untuk hampir semua senyawa dengan berat molekul rendah seperti saponin dan flavonoid (Wijesekera, 1991 dalam Lusiana 2014), jenis pengekstraksi juga mempengaruhi jumlah senyawa aktif yang terkandung dalam ekstrak, sesuai konsep like dissolve like, dimana senyawa yang bersifat polar akan larut dalam pelarut polar dan senyawa yang bersifat non polar akan larut dalam pelarut non polar (Lusiana 2014).

Flavonoid bersifat polar sehingga dapat dilarutkan menggunakan etanol (Saifudin dkk, 2006 dalam Latifah 2006). Dalam penelitian Heryanto dkk 2014 menyatakan etanol 80\% dapat melarutkan senyawa fitokimia secara maksimal dan mampu menarik beberapa senyawa fitokimia seperti alkaloid, flavonoid, glikosida flavonoid serta klorofil yang terlarut dalam pelarut polar, dari hasil penelitianya senyawa-senyawa yang diekstrak oleh pelarut $80 \%$ cukup banyak dan menghasilkan rendemen yang tinggi.

Pada penelitian ini digunakan tikus sebagai hewan percobaan karena keunggulannya, yaitu perkembangbiakan cepat, mempunyai ukuran yang lebih besar dari mencit, mudah dipelihara dalam jumlah yang banyak, dan tikus putih dipilih karena tikus memiliki proses absorbsi sistem pencernaan dan sistem metabolisme terhadap obat uji yang relatif mirip dengan sisitem pencernaan manusia (Akbar, 2010).

Pemilihan Pemilihan tikus jantan sebagai hewan uji karena tikus jantan memiliki kestabilan hormonal dibanding tikus betina, karena tikus betina mengalami siklus estrus masa kehamilan dan menyusui yang akan mempengaruhi kondisi psikologi hewan uji, tikus jantan tidak memiliki hormone estrogen, walaupun adanya jumlahnya sangat sedikit (Yasinta dkk, 2017).

Sebagai kontrol positif pada penelitian ini digunakan Natrium diklofenak, Natrium 
diklofenak merupakan turunan dari asam fenil asetat dan termasuk golongan obat non steroid yang paling kuat daya antiradangnya dengan efek samping yang kurang keras dibandingkan dengan obat lainnya seperti indometasin dan piroxicam. Penggunaan jangka panjang dianjurkan dengan tambahan suatu penghambat asam lambung guna mencegah terjadinya tukak lambung (Gunawan, 2007).

Pada pengujian antiinflamasi menggunakan metode pembentukan udem buatan pada telapak kaki tikus dengan menggunakan karagenan 1\% sebagai penginduksi. Karagenan dipilih untuk menguji obat antiinflamasi karena tidak bersifat antigenik dan tidak menimbulkan efek sistemik (Chakraborty et al., 2004 dalam Nur Annis 2008).

Penggunaan Karagenan sebagai penginduksi radang memiliki beberapa keuntungan antara lain tidak meninggalkan bekas, tidak menimbulkan kerusakan jaringan, dan memberikan respon yang lebih peka terhadap obat antiinflamasi dibandingkan dengan senyawa iritan lainnya (Siswanto dan Nurulita, 2005 dalam Endah 2013). Udem yang disebabkan oleh karagenan bisa bertahan selama 6 jam dan berangsur-angsur berkurang dalam waktu 24 jam. Udem yang terjadi akibat terlepasnya mediator inflamasi seperti histamin, bradikinin, dan prostaglandin (Cosini et al, 2005 dalam Tanti dkk 2012).

Pada penelitian ini, Pengujian antiinflamasi diukur sebelum perlakuan dan sesudah perlakuan pada jam ke- 2, 3, 4, dan 5. Data yang terkumpul merupakan data ketebalan udem pada telapak kaki tikus, rata-rata ketebalan udem tiap waktu pengamatan dapat dilihat pada tabel 1 .

Tabel 1 Rata-rata ketebalan udem telapak kaki tikus setelah insduksi karagenan pada masingmasing perlakuan

\begin{tabular}{cccccc}
\hline & \multicolumn{5}{c}{ Rata-rata ketebalan udem (mm) tiap jam } \\
Kelompok & \multicolumn{5}{c}{$\bar{x} \pm$ SD } \\
\cline { 2 - 6 } Perlakuan & T0 & T2 & T3 & T4 & T5 \\
& $(\mathbf{A})$ & $\mathbf{( B )}$ & $\mathbf{( C )}$ & $\mathbf{( D )}$ & $\mathbf{( E )}$ \\
\hline Kontrol & 0,407 & 0,515 & 0,601 & 0,693 & 0,704 \\
Negatif & \pm & \pm & \pm & \pm & \pm \\
& 0,083 & 0,050 & 0,098 & 0,119 & 0,119 \\
\hline Kontrol & 0,377 & 0,422 & 0,521 & 0,664 & 0,552 \\
Positif & \pm & \pm & \pm & \pm & \pm \\
& 0,052 & 0,025 & 0,092 & 0,048 & 0,101 \\
\hline Dosis & 0,362 & 0,448 & 0,662 & 0,634 & 0,557 \\
50mg/kg & \pm & \pm & \pm & \pm & \pm \\
BB & 0,052 & 0,101 & 0,104 & 0,086 & 0,072 \\
\hline Dosis & 0,398 & 0,568 & 0,727 & 0,712 & 0,604 \\
150mg/kg & \pm & \pm & \pm & \pm & \pm \\
BB & 0,090 & 0,137 & 0,082 & 0,084 & 0,145 \\
\hline Dosis & 0,354 & 0,415 & 0,684 & 0,645 & 0,545 \\
250mg/kg & \pm & \pm & \pm & \pm & \pm \\
BB & 0,087 & 0,072 & 0,106 & 0,082 & 0,070 \\
\hline
\end{tabular}

Keterangan:

T0 (A): Ketebalan udem sebelum diberikan perlakuan T2 (B): Ketebalan udem 2 jam setelah diberikan induksi T3 (C): Ketebalan udem 3 jam setelah diberikan induksi T4 (D): Ketebalan udem 4 jam setelah diberikan induksi T5 (E): Ketebalan udem 5 jam setelah diberikan induksi

Untuk mempermudah pengamatan, hasil ketebalan udem tiap waktu pengamatan dapat dilihat pada gambar 1

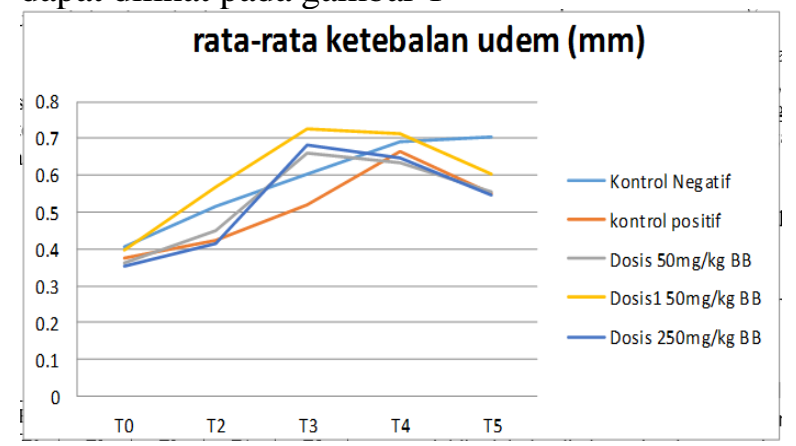

Gambar 1 Diagram garis hubungan rata-rata ketebalan udem

Pada gambar 1 menunjukan peningkatan ketebalan udem pada kontrol negatif setiap jam nya. Kemudian pada kontrol positif meningkat sampai jam 4 dan mulai menurun pada jam 5 . Sedangkan pada dosis $50 \mathrm{mg} / \mathrm{kg}$ BB, dosis $150 \mathrm{mg} / \mathrm{kg} \mathrm{BB}$, dan dosis $250 \mathrm{mg} / \mathrm{kg}$ BB hasil menunjukan bahwa ketebalan udem meningkat pada jam ke 3 dan mulai menurun pada jam ke 4 dan ke 5

Berdasarkan data tabel 1 selanjutnya dapat dihitung persentase rata-rata udem pada telapak kaki tikus setelah induksi karagenan pada masingmasing perlakuan, hasil pengujian dapat dilihat pada Tabel 2.

Tabel 2 Rata-rata persen udem telapak kaki tikus setelah insduksi karagenan pada masing-masing perlakuan

\begin{tabular}{|c|c|c|c|c|c|}
\hline \multirow{2}{*}{$\begin{array}{l}\text { Kelompok } \\
\text { Perlakuan }\end{array}$} & \multicolumn{5}{|c|}{$\begin{array}{c}\text { Rata-rata Persen Udem (\%) tiap jam } \\
\bar{x} \pm \text { SD }\end{array}$} \\
\hline & T0 & T2 & T3 & T4 & T5 \\
\hline $\begin{array}{c}\text { Kontrol } \\
\text { Negatif }\end{array}$ & $0 \pm 0$ & $\begin{array}{c}30,92 \\
\pm \\
29,93\end{array}$ & $\begin{array}{c}49,58 \\
\pm \\
18,86\end{array}$ & $\begin{array}{c}72,59 \\
\pm \\
26,55\end{array}$ & $\begin{array}{c}78,55 \\
\pm \\
50,17\end{array}$ \\
\hline $\begin{array}{l}\text { Kontrol } \\
\text { Positif }\end{array}$ & $0 \pm 0$ & $\begin{array}{c}13,47 \\
\pm \\
15,92\end{array}$ & $\begin{array}{c}37,92 \\
\pm \\
10,89\end{array}$ & $\begin{array}{c}79,11 \\
\pm \\
30,90\end{array}$ & $\begin{array}{c}47,85 \\
\pm \\
26,95\end{array}$ \\
\hline $\begin{array}{c}\text { Dosis } \\
\text { 50mg/kg } \\
\text { BB }\end{array}$ & $0 \pm 0$ & $\begin{array}{c}25,91 \\
\pm \\
35,65\end{array}$ & $\begin{array}{c}84,01 \\
\pm \\
25,82\end{array}$ & $\begin{array}{c}76,61 \\
\pm \\
23,81\end{array}$ & $\begin{array}{c}56,94 \\
\pm \\
34,25\end{array}$ \\
\hline $\begin{array}{c}\text { Dosis } \\
150 \mathrm{mg} / \mathrm{kg} \\
\mathrm{BB}\end{array}$ & $0 \pm 0$ & $\begin{array}{c}43,98 \\
\pm \\
26,14\end{array}$ & $\begin{array}{c}88,77 \\
\pm \\
38,65\end{array}$ & $\begin{array}{c}84,59 \\
\pm \\
36,67\end{array}$ & $\begin{array}{c}54,26 \\
\pm \\
35,83\end{array}$ \\
\hline $\begin{array}{c}\text { Dosis } \\
250 \mathrm{mg} / \mathrm{kg} \\
\mathrm{BB}\end{array}$ & $0 \pm 0$ & $\begin{array}{c}20,17 \\
\pm \\
21,19\end{array}$ & $\begin{array}{c}97,95 \\
\pm \\
28,87\end{array}$ & $\begin{array}{c}90,91 \\
\pm \\
54,53\end{array}$ & $\begin{array}{c}64,51 \\
\pm \\
60,39\end{array}$ \\
\hline
\end{tabular}


Untuk mempermudah pengamatan, hasil ketebalan udem tiap waktu pengamatan dapat dilihat pada gambar 2

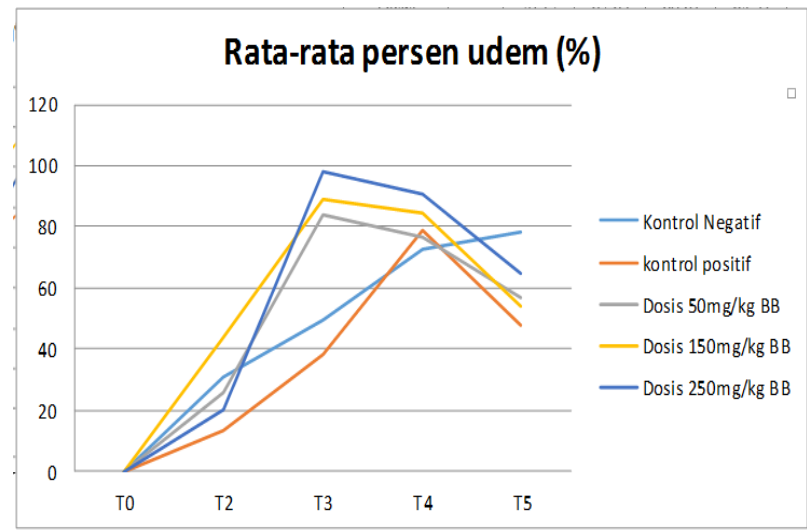

Gambar 2 Diagram garis hubungan rata-rata persen ketebalan udem

Dari gambar 2 dapat dilihat pada semua dosis kelompok zat uji menunjukan adanya efek antiinflamasi dimana persen udem rata-rata setiap kelompok zat uji tidak sebesar persen udem pada kelompok kontrol negatif. Pada kelompok kontrol negatif yang diberi CMC Na $0,5 \%$, persen udem trus meningkat mulai jam ke 2 sampai jam ke 5, pada kelompok zat uji kontrol positif mengalami peningkatan persentase udem terjadi jam ke 2 sampai jam ke 4 dan mengalami penurunan jam ke 5.

Sedangkan kelompok zat uji dosis pertama, dosis kedua dan dosis ketiga persen udem tertinggi pada jam ke 3 dan menurun pada jam ke 4 dan ke 5. Pada rata-rata persen udem pada kelompok dosis $250 \mathrm{mg} / \mathrm{kg}$ BB lebih besar dibandingkan dengan kelomok dosis $50 \mathrm{mg} / \mathrm{kg} \mathrm{BB}, 150 \mathrm{mg} / \mathrm{kg} \mathrm{BB}$, dan kontrol positif.

Sedangkan rata-rata persen udem pada dosis $150 \mathrm{mg} / \mathrm{kg}$ BB lebih kecil dari persen dosis $50 \mathrm{mg} / \mathrm{kg}$ BB dan $250 \mathrm{mg} / \mathrm{kg}$ BB. Sehingga pemberian ekstrak etanol daun salam india dengan dosis $150 \mathrm{mg} / \mathrm{kg}$ BB merupakan dosis yang berpotensi tinggi dalam menghambat udem, hal ini terlihat dari persentase penghambatan terbesar. Suatu bahan dikatakan memiliki efek antiinflmasi jika pada hewan coba yang diinduksi karagenan $1 \%$ mengalami pengurangan pembengkakan hingga 50\% atau lebih (Utami et al,2011 dalam Ira Sukainan 2013).

Data ketebalan udem pada masing-masing kelompok diuji normalitasnya menggunakan uji Kolmogorov Smirnov. Pada uji normalitas diperoleh hasil sebaran data terdistribusi normal. Kemudian dilanjutkan dengan uji homogenitas, menunjukkan nilai $(\mathrm{p}>0.05)$, yang artinya data bervariasi homogen. Untuk melihat apakah ada perbedaan yang signifikan dari lima kelompok maka dilakukan uji Anova. Hasil pengujian Anova dapat diihab pada table 3

Tabel 3. Uji One-Way ANOVA

\begin{tabular}{lll}
\multicolumn{1}{c}{ Kelompok subjek } & & Sig. \\
\hline T0(A) & .769 & \\
\hline T2(B) & .000 & \\
\hline T3(C) & .113 \\
\hline T4(D) & .214 \\
\hline T5(E) & .003 & \\
&
\end{tabular}

Sesuai Tabel 3. di atas menunjukkan bahwa analisis kemaknaan dengan uji One Way ANOVA didapat bahwa ketebalan udem pada jam ke 2 dan jam ke 5 berbeda secara bermakna, hal ini terlihat dari nilai $\mathrm{p}$ ketebalan udem yang terdapat pada tabel 3 yaitu 0,000 dan 0,003 lebih kecil dari 0,05 $(p<0,05)$. Selanjutnya untuk mengetahui perbedaan hasil uji bermakna antara kontrol negatif, kontrol positif, dosis $50 \mathrm{mg} / \mathrm{kg} \mathrm{BB}$, dosis $150 \mathrm{mg} / \mathrm{kg} \mathrm{BB}$, dan dosis $250 \mathrm{mg} / \mathrm{kg}$ BB dilanjutkan dengan uji beda nyata terkecil (BNT) dengan metode LSD, hasil dapat dilihat pada tabel 4 .

Table 4. Komparasi Antar Kelompok Penurunan Ketebalan Sesudah Perlakuan

\begin{tabular}{|c|c|c|c|c|c|c|}
\hline \multirow[b]{2}{*}{$\begin{array}{c}\text { Kelom } \\
\text { pok }\end{array}$} & \multirow[b]{2}{*}{$\begin{array}{c}\text { Kelo } \\
\text { mpok }\end{array}$} & \multicolumn{5}{|c|}{ Sig. } \\
\hline & & $\begin{array}{l}\text { T0 } \\
\text { (A) }\end{array}$ & $\begin{array}{l}\text { T2 } \\
\text { (B) }\end{array}$ & $\begin{array}{l}\text { T3 } \\
\text { (C) }\end{array}$ & $\begin{array}{l}\text { T4 } \\
\text { (D) }\end{array}$ & $\begin{array}{l}\text { T5 } \\
\text { (E) }\end{array}$ \\
\hline \multirow{4}{*}{ KN } & $\mathrm{KP}$ & .536 & .000 & .017 & .421 & .002 \\
\hline & P1 & .363 & .000 & .489 & .197 & .002 \\
\hline & P2 & .852 & .120 & .152 & .023 & .000 \\
\hline & P3 & .279 & .000 & .689 & .265 & .001 \\
\hline \multirow{3}{*}{ KP } & P1 & .756 & .651 & .071 & .613 & .936 \\
\hline & P2 & .664 & .005 & .274 & .116 & .460 \\
\hline & P3 & .635 & .903 & .039 & .748 & .888 \\
\hline \multirow{2}{*}{ P1 } & P2 & .459 & .014 & .441 & .272 & .413 \\
\hline & P3 & .868 & .567 & .769 & .853 & .825 \\
\hline P2 & P3 & .367 & .004 & .291 & .203 & .548 \\
\hline
\end{tabular}

Keterangan:

$\mathrm{KP}:$ Kontrol positif

$\mathrm{KN}$ : Kontrol negatif

$\mathrm{P} 1$ : Dosis $50 \mathrm{mg} / \mathrm{kg} \mathrm{BB}$

P2: Dosis $150 \mathrm{mg} / \mathrm{kg} \mathrm{BB}$

P3 : Dosis $250 \mathrm{mg} / \mathrm{kg}$ BB

Hasil tes LSD menunjukan bahwa esktrak etanol daun salam india dosis $50 \mathrm{mg} / \mathrm{kg}$ BB, $150 \mathrm{mg} / \mathrm{kg}$ $\mathrm{BB}, 250 \mathrm{mg} / \mathrm{kg}$ BB dan kontrol positif menunjukan perbedaan yang bermakna dengan kontrol negatif $(\rho<0,05)$ pada jam ke 5 . Hal ini menunjukan bahwa ekstrak daun salam india dosis $50 \mathrm{mg} / \mathrm{kg} \mathrm{BB}$, $150 \mathrm{mg} / \mathrm{kg} \mathrm{BB}, 250 \mathrm{mg} / \mathrm{kg}$ BB dan kontrol positif berpotensi mengurangi ketebalan udem dan kemampuan menghambat udem pada telapak kaki 
tikus. Selanjutnya pada dosis $50 \mathrm{mg} / \mathrm{kg} \mathrm{BB}$, $150 \mathrm{mg} / \mathrm{kg} \mathrm{BB}, 250 \mathrm{mg} / \mathrm{kg}$ BB tidak menunjukan perbedaan yang bermakna dengan kontrol positif $(\rho>0,05)$ sehingga dapat dinyataka bahwa dosis $50 \mathrm{mg} / \mathrm{kg} \quad \mathrm{BB}, \quad 150 \mathrm{mg} / \mathrm{kg}$ BB, $250 \mathrm{mg} / \mathrm{kg}$ BB memiliki efek yang sama dengan kontrol positif. Tetapi dosis $50 \mathrm{mg} / \mathrm{kg} \mathrm{BB}, 150 \mathrm{mg} / \mathrm{kg} \mathrm{BB}$, dan $250 \mathrm{mg} / \mathrm{kg}$ BB menunjukan penurunan antinflamasi yang mendekati sehingga pada uji anova tidak menunjukan perbedaan yang bermakna.

Berdasarkan hasil maka penurunan yang berpotensi tinggi menurunkan antiinflamasi dapat dilihat dari persentase, dimana dosis $150 \mathrm{mg} / \mathrm{kg} \mathrm{BB}$ memiliki persentase penghambatan terbesar. Dosis $150 \mathrm{mg} / \mathrm{kg}$ BB menurunkan antiinflamasi terbesar dibandingkan dengan dosis $250 \mathrm{mg} / \mathrm{kg} \mathrm{BB}$, hal ini kemungkinan karena ekstrak etanol daun salam india dosis $250 \mathrm{mg} / \mathrm{kg}$ BB mempunyai toksisitas yang lebih tinggi. Menurut penelitian Meilawati (2013) pada tanaman daun singkong (Manihot utilissima) konsentrasi obat atau bahan alami yang besar dapat menyebabkan toksisitas yang besar pula.

Dari hasil penelitian ini menunjukan bahwa ekstrak etanol daun salam india dapat menurunkan antiinflamasi. Aktivitas antiinflamasi esktrak etanol daun salam india diperkirakan berkaitan dengan penghambatan pembentukan siklooksigenase. Flavonoid adalah senyawa yang diduga berperan memiliki efek antiinflamasi yang mekanisme kerjanya diduga menghambat jalur siklooksigenase pada jalur metabolisme asam arakidonat, dan saponin yang hampir sama dengan flavonoid memblokir jalur prostaglandin.

\section{SIMPULAN}

1. Ekstrak Etanol Daun salam india dengan dosis $50 \mathrm{mg} / \mathrm{kg} \mathrm{BB}, 150 \mathrm{mg} / \mathrm{kg} \mathrm{BB}$, dan $250 \mathrm{mg} / \mathrm{kg}$ BB dapat menghambat udem pada telapak kaki tikus yang telah diinduksi oleh karagenan $1 \%$ sebanyak $0.1 \mathrm{ml}$.

2. Dosis $150 \mathrm{mg} / \mathrm{kg}$ BB memiliki efek antiinflamasi tertinggi dilihat dari persentase penghambatan terbesar.

\section{DAFTAR PUSTAKA}

Akbar, Budhi. 2010, Tumbuhan dengan Kandungan Senyawa Aktif yang Berpotensi Sebagai Bahan Antifertilitas Ed. 1, Jakarta: Adabia Press.
Dewato, Hedi R. 2007, Pengembangan Obat Tradisional Indonesia Fitofarmaka, Maj Kedokt Indon, Vol. 57, No. 7.

Dheeraj dkk. 2014, Murraya Koenigii buah Etnobotani, Fitokimia Dan Farmakologi Ulasan Jurnal Farmakognosi Dan Fitokimia,Vol. 3 No.3:109-119.

Dorland, W.A. Newman. 2002, Kamus Kedokteran Dorland, Edisi 28, Jakarta: Buku Kedokteran EGC.

Endah P. 2013, Uji Efek Antiinflamasi Ekstrak Etanol Lumut Hati Mastigophora diclados (Bird, ex Web.) Nees secara In Vivo. Tesis, Fakultas Kedokteran Ilmu Kesehatan, Jakarta.

Gunawan, S.G. 2007, Farmakologi dan Terapi edisi 5, Jakarta: Balai Penerbit FKUI.

Heryanto M, Max Revolta, Sri Sudewi. 2014, Aktivitas Antioksidan Daun Kayu Bulan (Pisonia Alba), Pharmacon Jurnal Ilmiah Farmasi- Unsrat, Vol 3 No. 3

Ira Sukaina. 2013, Uji Efek Antiinflamasi Ektrak Etanol Herba Kemangi (Ocimum Americanum Linn) Terhadap Udem Pada Telapak Kaki Tikus Putih Jantan Yang Diinduksi Karagenan. Skripsi, Fakultas Kedokteran dan Ilmu Kesehatan Program Studi Farmasi Jakarta.

Latifah. 2015, Identifikasi senyawa golongan flavonoid dan uji aktivittas antioksidan pada ekstrak rimpang Kencur kaempferia galangal L, dengan metode DPPH (1,1DIFENIL-2-PIKRILHIDRAZIL). Skripsi, Jurusan Kimia Fakultas Sains dan Teknologi.

Lusiana, Rice, dan Idha. 2014, Pengaruh Jenis Pelarut Pengektraksi Terhadap Kadar Sinensetin Dalam Ekstrak Daun Orthosiphon stamineus Benth. Pengaruh Jenis Pelarut Pengektraksi E-Journal Planta Husada Vol.2, No.1 April 2014.

Margareta. 2016, Uji Aktivitas Antioksidan Dan Penetapan Kadar Fenolik Total Ekstrak Etanol Buah Buni (Antidesma Bunius L.Spreng) Dengan Metode 2,2-Diphenyl1-Picrylhydrazyl (DPPH) Dan Metode Folin-Ciacolteu. Skripsi, Fakultas Farmasi Univesitas Sanata Dharma Yogyakarta. 
Meilawati. 2013, Efek Ekstrak Daun Singkong (Manihot Utilissima) Terhadap Ekspresi COX-2 Pada Monosit Yang Dipapar LPS E.Coli. Dent. J. (Maj. Ked. Gigi), Vol 46, No 4.

Nur Annis, shanti listyawati, ahmad dwi setyawan. 2008, Kandungan Kimia dan Uji Antiinflamasi Ekstrak Etanol Lantana camara L. pada Tikus Putih (Rattus norvegicus L.) Jantan, Bioteknologi 5 (1): $10-17$

Risna Agustina, Dewi Tita, Muhammad Amir. 2015, Aktivitas ekstrak daun salam (eugenia polyantha) sebagai antiinflamasi pada tikus putih (rattus norvegicus), J. Trop. Pharm. Chem. Vol 3. No. 2
Rastina, Mirnawati Sudarwant dan Ietje Wientarsih. 2015, Aktivitas antibakteri ekstrak etanol daun kari (murraya koenigii) terhadap staphylococcus aureus, Escherichia coli, dan pseudomonas sp, Jurnal Kedokteran Hewan Vol. 9 No. 2

Richard A, Harvey, dan Pamela C. 2014, Farmakologi Ulasan Bergambar, edisi 4, Jakarta : EGC.

Tanti, Raudatul, dan Ratna. 2012, Efek Antiinflmasi Infusa Rimpang Temu Putih (Curcuma Zedoaria (Berg) Roscoe) Pada tikus yang diinduksi karagenin. Biomedika ,Vol. 4. No.2

Yasinta, Hatuti, Joni, dan Sri. 2017, Efektivitas Antihiperurisemia Ektrak Etanol Daun Seledri (EEDS) Pada Tikus Induksi Kalium Oksonat. J Trop Pharm. Chem. Vol 4. No 1. 